\title{
The Experiences of Members of the School Governing Bodies in Executing their Duties during the COVID-19 Pandemic Lockdown
}

\author{
Ntombozuko Duku \\ ORCID iD: https://orcid.org/0000-0002-2897-5091
}

Mzuyanda Percival Mavuso

ORCID iD: https://orcid.org/0000-0002-2398-7325

\author{
Moses Sipho Mkhomi \\ ORCID iD: https://orcid.org/0000-0003-3314-031X
}

\section{Abstract}

The education sector has been negatively affected by COVID-19's impact. Schools had to minimise face-to-face interactions, adhere to the legislated COVID-19 protocols that include social distancing, the use of sanitisers, and the wearing of masks. Also, there was the banning of social gatherings, which amongst others, led to school closures. When the schools reopened, many were forced to adopt the learner rotation system, to ensure social spacing. Consequently, teaching and learning was also done using Information and Communication Technology (ICT), which became 'the new normal'. However, little is known of how the SGBs executed and experienced their duties during the COVID-19 lockdown. This paper, therefore explored how School Governing Bodies (SGBs) of three selected schools experienced their duties, including discussing and communicating decisions during the COVID-19 lockdown. Literature reports that pre-COVID-19, SGBs made use of face-to-face methods to debate and execute their duties. In the absence of the face-to-face interaction as enforced by COVID-19 lockdown, it then becomes unclear how they would execute their duties. Hence this paper aimed to explore the SGBs' experiences in executing their duties during COVID-19 lockdown. This study used the qualitative approach, Phenomeno- 
logical Telephone Assisted Interviews, using IsiXhosa and English as languages of data collection. Thematic data analysis strategy was used to analyse the data. Using Van Manen's Theory of Lived Experiences, due to the changed circumstances as affected by COVID-19 lockdown, the participants used WhatsApp messaging, Short Message Service (SMS) as well as Voice Calls as a medium of communicating decisions. These were, however, experienced with some degrees of frustration as they were challenged by unstable network coverage, data availability, advanced age and education levels of some SGB members. Nevertheless, they are learning to embrace mobile phones as the 'Tools of Work' for the future. Furthermore, SGBs were reportedly informed of decisions taken with reference to school governance, even though no formal meeting took place. The study recommended that ICT gadgets, including cell phones, laptop computers and data availability be part of the SGB induction and training package offered by the Department of Basic Education (DBE). Moreover, the generational mix in the SGBs composition would benefit governing of schools as they may be more comfortable working with modern technologies.

Keywords: school governance, school governing bodies; governance duties; lived-experiences.

\section{Introduction}

The aim of this research was to explore how the selected School Governing Bodies (SGBs) experienced their duties during coronavirus disease 2019 (COVID-19) lockdown. During the COVID-19 lockdown, the protocols and regulations discouraged face-to-face interactions, which pre-COVID-19, were the main methods of debating and decision making. Literature reports that pre-COVID-19, the SGBs mainly made use of face-to-face methods to debate and execute their duties (Duku 2006; Duku \& Brown 2008; Mavuso \& Duku 2014). In the absence of the face-to-face interaction, as enforced by COVID-19 lockdown, it then becomes unclear how they would execute their duties. COVID-19 lockdown forced organisations to work virtually and online (Sayed \& Singh 2020; Soudien 2020). Such organisations included schools that were to use virtual means for teaching and learning, and by implications, leadership and management and governance duties. Hence, it 
became imperative that this paper explore the experiences of the SGBs in the execution of their duties during COVID-19 pandemic lockdown.

\section{Background and Problem Setting}

Worldwide, school governance, which pronounces the participation of all school constituencies is a crucial phenomenon legislated by different nations (Mavuso 2009; Mavuso \& Duku 2014; Duku \& Salami 2017; McCrone et al. 2011, Mncube 2009, Chikoko 2008; Peacock 2006). While there is considerable variation in the way it is defined, it is part of the process and systems that the school operates within (Duku \& Salami 2017). Furthermore, Duku and Salami (2017), are of the view that the aim of school is to promote community participation. It, therefore, ensures local accountability and promotes educational transformation (Mncube 2009). Levy and Shumane (2017) link school governance with endeavours to enhance the Millennium Development Goal of universal access to education. As a result, in South Africa, the SGB is an institutional structure entrusted with the authority to formulate and adopt school policies (Mncube 2009). Such policies are expected to promote democracy and form a bridge between the schools and the communities they serve. This may be the rationale that different countries such as South Africa, Zimbabwe, England and Wales are following (Mavuso 2009). In countries such as England, Wales and France, the school governance system was legislated as early as the 1980s (Farrell \& Law 1999). Although the SGBs in South Africa were only legislated in 1996 and first implemented in 1997, in other countries such as Zimbabwe, Kenya and Botswana, school governance was legislated long before 1996 (Kombela 2019).

With the promulgation of the South African Schools Act, No. 84 of 1996 (SASA), the government had hoped to foster democratic governance of schools by active participation of school constituencies, characterised by robust debates, inclusiveness, tolerance and collective decision-making. With regards to the democratic participation and robustness of debates, the majority of research indicates challenges and limitations regarding the quality of participation, especially by the parent-component of the SGB (Mncube 2007; Duku \& Brown 2008; Mavuso \& Duku 2014; Levy \& Shumane 2017). These studies also link the importance of context in SGBs and distinguish governance arrangements and stakeholder influence (Levy 
and Shumane 2017). For instance, the identity of parent members of an SGB becomes an important factor. Duku and Brown (2008) as well as Xaba (2011) found that the majority of parents, particularly in rural areas participating in SGBs were reportedly of official pension age, and not literate, which affect their quality of engagement in meetings. Moreover, and most importantly, SGB engagements were mainly face-to-face as well as through letters that were given to the learners to pass to their parents or guardians (Duku 2006). The outbreak of COVID-19 in March 2020, and the subsequent lockdowns prevented these modes of interaction, and compelled SGBs to use alternative ways of interaction. For instance, in teaching and learning, technology such as emails, Zoom, Smart Teams, WhatsApp messages, etc. were reportedly used (Soudien 2020; Sayed \& Singh 2020). One wonders how the rural SGBparent members, reported to be old and functionally illiterate (Mavuso \& Duku 2014) experienced the COVID-19 lockdown restrictions in the execution of their governance duties. Their duties include amongst others, the formulation of school-based policies, financial management and general governance decision making (SASA 1996). Hence the focus of the research was to unearth the experiences of the selected SGBs in the execution of their governance duties during the COVID-19 lockdown.

The outbreak of the COVID-19 pandemic was declared a Public Health Emergency of International Concern (United Nations Children's Emergency Fund (UNICEF) 2020) which necessitated the World Health Organization (WHO) to declare precautionary measures to prevent its spread. The major precautionary measures involved the use of face masks, hand washing or sanitisation and social distancing, which subsequently were also enforced in schools (Soudien 2020). Another implication of COVID-19 was that schools needed to adapt their policies, including academic calendar changes (UNICEF 2020). In South Africa, after the first COVID-19 recorded case on 5th March 2020, the Government declared COVID-19 a national disaster in terms of the Disaster Management Act (RSA, 2020). As cases of infection rose, the government closed schools from 18th March to 14th April, and then from 27th July to 24th August. During this period, media was abuzz, calling for the use of online teaching and learning (City Press 2020; IOL 2020). Thus, virtual and online teaching and learning was experienced differently, depending on the economic context of the school (City Press 2020). 
Whilst the Department of Basic Education (DBE) took the decision to close and open schools, community voices were not audible enough in school-based policy debates. It was the five major teacher unions in SA that debated and forced the Minister of Basic Education to close down the schools (City Press 2020; IOL EWN 2020). In the Eastern Cape, it was the sole voice of Northern Areas SGB Forum that ordered immediate closure of Qhebera schools (IOL 2020). The pandemic therefore necessitated the SGBs to explore other means of holding meetings and discussing policy matters. There is however very little research on how SGBs at grassroots levels engaged with school-based policies. Hence this research explored the SGBs' experiences in executing their duties, including communicating school-based policy decisions during COVID-19 lockdown.

\section{Research Questions}

- How do SGB members experience the execution of their duties during COVID-19 lockdown?

- What methods did the participants use for the execution of their duties?

- Why did participants prefer the particular methods?

- On the basis of the findings, how can school governance be enhanced during the COVID-19 era?

\section{The Purpose of the Study}

Currently there is not much research on the experiences of SGBs in executing their duties during the COVID-19 lockdown, in South African schools. As indicated in earlier sections, SGBs executed their duties using face-to-face approaches (Duku 2006; Mavuso \& Duku 2014). Yet COVID-19 lockdown protocols included limited or no face-to-face contact, which were also applicable to school leadership management and governance. This study thus aimed to explore the experiences of SGBs in executing their duties during the COVID-19 lockdown. 


\section{Theoretical Framework: Theory of Lived Experiences}

This study is informed by Van Manen's $(1990 ; 2017)$ Theory of Lived Experiences. Van Manen explains lived experiences as the 'life-world' of a person's experience so that the researchers can gain a deeper understanding of lived experiences, perceptions and understanding of their world. In so doing, experiences provide the experiencer self-awareness of life, and an ability to identify, clarify and self-examine certain situations Van Manen (2017) sees the benefits of studying experiences, as giving the experiencer an opportunity to reflect on what it is like to experience a particular phenomenon. In this study, the SGB members - the experiencers - are reflecting on the phenomenon (lived experiences in executing their duties) during COVID-19 lockdown. They reflected on how they functioned as a result of the new context (COVID-19 lockdown). They also reflected on the feelings experienced, how they behaved and acted towards the experience (executing their governance duties). This approach asserts that our conscious experience is directed towards, 'intends' or represents a phenomenon through particular concepts, thoughts, ideas and feelings of a given experience. As the experiencer reflects on the phenomenon, deep meanings from the phenomenon lived are revealed and therefore bring opportunities for selfawareness (Van Manen 1990).

The 'breathing of meaning' as implied by Van Manen (1990) may lead to the SGBs to reflect on what and how they have done during COVID19 lockdown and try to identify the essence of their experience. Through the lived experiences, new descriptions and methods relating to what and how they executed their duties during and pre-COVID-19 lockdown may be proposed.

\section{Literature Review \\ 6.1 The Notion of School Governance}

School governance is a worldwide phenomenon, practised differently by different countries. For instance, Switzerland's school governance is along the lines of federal government with the school system lying within the 26 cantons or districts. Each canton or district has its school system and, in each canton or district, decisions are taken at different levels of political decision making (Huber 2011). This is the macro level of school governance. At the meso level, school governance is linked with local municipalities and at 
micro level, principals and School Management Teams (SMTs) handle issues of school governance (Huber 2011). In England, as in South Africa, each school has its own governing body whose role is to ensure that schools perform and continually seek to improve what they do. As schools are ever changing institutions, SGBs have to move with the pace of educational developments (Balarin, Brammer, James \& McCormack, 2008). And thus, the outbreak of COVID-19 presented opportunities for new adaptations on how school school-based policies are developed.

School governance is characterised by creating, implementing, supervising and evaluating policies and rules of the school (Bayat et al. 2014) and therefore, refers "to the "patterns of rule" which are concerned with regulation, direction and procedure' (Balarin et al. 2008, p.10). Similarly, The South African Schools Act of 1996, provides that the governance of a public school is vested in the SGB that stands in the position of trust towards the school (Mestry 2006). Governance duties or roles of the SGBs are stipulated in SASA of 1996. In terms of SASA, Section 20 (RSA Contitution,1996), the SGBs have to; adopt SGB constitution, draft the mission statement of the school and draft a series of school-based policies, to mention just a few. From the legislative framework, it is apparent that community involvement is not only critical but also indispensable. This observation by the researchers of this paper is echoed by Bayat et al. (2014), that the SGB's role prior to the dawn of democracy was a top-down approach with parents and communities excluded from important decision-making for the schools. Although there is a plethora of research on school governance (Bush \& Heystek 2003; Duku \& Brown 2008; Mncube 2009; Heystek 2012 and Mavuso \& Duku 2014), there seems to be a dearth of literature that focuses on the experiences of SGBs in performing their duties during COVID-19 lockdown. Hence this paper sought to investigate SGBs' experiences in executing their duties during the COVID-19 lockdown. Literature, especially on school governance in rural schools, mainly report on SGBs executing their governance duties using face-to-face methods, characterised by, amongst others; reluctant participation, pseudoparticipation, which undermines democratic values, etc. (Duku 2006; Mavuso \& Duku 2014; Mncube 2008).

As a result of the context presented above, Bayat et al. (2014), assert that despite SGBs being empowered to make decisions for schools, schools still experience many challenges. These challenges include amongst others; 
poor attendance of meetings, lack of understanding of the core roles of governance and low levels of literacy among the school governors (Heystek 2003; Heystek 2011; Mncube 2009). The imposition of the COVID-19 lockdown, banned meetings and encouraged social distancing. Despite the outbreak of the COVID-19 pandemic, and subsequent closure of schools, SGBs still had a statutory duty to pay service providers, to fumigate the school buildings and provide security services for their schools. Thus Gann (1998) argues that SGBs have to perform an executive action - approving procurement of services and goods on behalf of the school. These governance duties required the SGBs to meet, communicate and make decisions on behalf of their schools. This assertion is in line with that of Mestry (2006), that a school is a juristic person with the legal capacity to perform its functions and the SGB act on behalf of the school. As part of its governance duties, an SGB has to identify statutory duties that need strategic decisionmaking (Knight 1998).

\subsection{School Governing Bodies and Management of Schools during COVID-19}

The COVID-19 pandemic has had far-reaching implications and consequences in the management and governance of South African schools. The unwavering desire to save the 2020 academic year by the DBE meant that learners and teachers had to be at school during a period of new infections. As infections increased, epidemiologists advised the government to close schools as lives of learners and teachers were at risk. This advice demanded a new way of operation, communication with the stakeholders and teaching and learning during the pandemic. Continued operations of schools during the pandemic, albeit on a limited scale, was in line with the objective of ensuring high quality education in schools (Heystek 2011).

In terms of the health protocols, schools were allowed to operate but were to strictly observe social distancing and other health protocols. To achieve successful operations, schools had to implement processes and procedures applicable to their contexts. This was a manifestation of selfmanagement of schools and decentralisation, in which schools took decisions on their own, with limited influence from district offices (Olssen \& Peters 2005). According to Caldwell and Spinks (1998), self-managing and decentralised schools are not autonomous, but the school community, SMTs 
and SGBs are entrusted to make decisions in the best interest of the school.

Similarly, Hargreaves (1994) echoes the view that self-managed schools rely on collaboration to implement their own and central government mandate. Mashego (2000) defines the concept of collaboration as a process of exchanging information, altering activities, sharing resources and enhancing others' capacity for their mutual benefit and to achieve common goals. Similarly, Lai (2011) defines collaboration as the mutual engagement of participants in a co-ordinated effort to solve a problem. In the context of this paper, this means communicating with stakeholders, using other means other than face-to-face approaches. This paper seeks to explore the experiences of the SGBs in executing their duties during the COVID-19 lockdown, in the absence of the traditional modes of interactions. Hence Heystek (2011) suggests that collaboration is a pre-requisite for SMTs and SGBs to achieve long- and short-term goals.

\subsection{Information and Communication Technology (ICT)}

Although the focus of this paper is on school leadership and management during the COVID-19 pandemic lockdown, it is imperative that ICTs are briefly explored as ICT tools are a crucial necessity for the smooth running of organisations in the $21^{\text {st }}$ century (Ratheeswari 2018; Padayachee 2017).

Information and Communication technology (ICT) refers to technologies that provide access to information through telecommunication, via the internet, wireless networks, cell phones and other means of communication. These technologies are making dynamic changes in society and are influencing all aspects of life, including schools (Ratheeswari 2018). However, a Turkish study found that, using ICT brought about costly challenges (Tosun $\&$ Bariş 2011). This finding is not an isolated challenge but prevalent in the South African education system, with its historical and structural inequalities. According to Munje and Jita (2020) SA schools are characterised by vandalism and theft, cases computer laboratories targeted in most cases, and therefore hampers the schools' chances of using ICT for teaching and learning. The ICT tools, according to Padayachee (2017), used in SA schools include data projectors, interactive white boards, e-books, smart phones, etc. The statistics, however, indicate that the majority of the schools' lack most of these ICT tools (Padayachee, 2017). This is despite the fact that ICT has become an effective factor in school improvement (Tosun \& Bariş 2011). 


\section{Significance of the Study}

This study will contribute to the existing body of literature on school governance and how SGBs could execute their duties during the COVID-19 era. The majority of literature mostly addresses the roles of SGBs and the challenges of school governance. It is therefore hoped that this study may assist SGBs to unearth a strategy to work and execute their duties effectively during the COVID-19 era. This paper might also contribute and add views to the capacitation of SGBs to cope with the 'new normal'. Furthermore, SGBs might be able to align their school policies with the Fourth Industrial Revolution (4IR).

\section{Research Methods and Methodology}

This qualitative study was premised on the interpretivist paradigm, which advocates that reality is complex, multi-layered and a single phenomenon can have multiple interpretations (Tashakkori \& Teddlie 2010). Interpretivist researchers believe in studying a phenomenon using techniques that help them understand how people interpret and interact within their social environment (Almalki 2016). The researchers gathered data from interviews and document reviews, rather than relying on a single data source (Creswell 2014). The work of the qualitative researcher is to review all data, make sense of it and organise it into themes. The meaning that participants give to a problem or issue is the focus of a qualitative researcher (Creswell, 2014) . In this study, in-depth telephone assisted semi-structured interviews and documentary reviews were used to collect data. Three SGB chairpersons and three principals were purposefully selected from three schools. Governance related documents were also analysed to establish how SGBs are using ICT in schools, as well as to ascertain whether schools have ICT policy in place.

\section{Data Analysis}

Data analysis is a process of inspecting, cleaning, transforming and packaging data to discover useful information, suggesting conclusions and supporting decision making (Babbie \& Mouton 2006; Okeke \& Van Wyk 2015). It is also defined as a process of bringing order, structure and meaning to the massive amount of data collected (De Vos et al. 2005). It is a process of working with data, organising it, breaking it into manageable units, 
synthesising it and searching for emerging patterns and repetitive thoughts and patterns that link participants to the setting (Maree 2007; Creswell 2014). The researchers identified themes from the data using codes to express the identified themes (Ibrahim 2012). Such themes were connected to the raw collected data and summarised. Such raw data was mainly from open-ended interviews.

\section{Ethical Considerations}

To comply with ethical considerations, the researchers, before collecting data, sought an ethical clearance certificate from the University of Fort Hare's relevant committees such as Faculty of Education Research Ethics Committee, the Inter-Faculty Research Ethics Committee and the University Research Ethics Committee. Anonymity and confidentiality were also taken into consideration. Participants and their research sites remained anonymous, that is, their personal details were not required during the interview apart from their positions within the organisation, their gender and age. According to Fraenkel and Wallen (2006) and Sotuku and Duku (2015), data should be handled carefully and in confidence to protect participants.

Participation was voluntary from two school principals and the SGB members who were purposefully in selected of the rural schools in Eastern Cape Province, South Africa. Ethical Procedures were observed and the researchers explained to participants that they had the right to withdraw from participation at any time if they so wished. This means that participants were not intimidated into participating in this study but gave informed consent (Sotuku \& Duku 2015).

\section{FINDINGS}

Guided by the research questions, the following themes were identified:

\section{(a) Introducing the Participants and the Research Sites}

The participating SGB chairpersons and school principals were all African males. Gender skewness of the SGB chairpersons may imply that in these schools, males are still preferred in leadership positions, which is a traditional view. The SGB chairpersons had varied levels of education, of 
Grades 8,6 and 3, respectively. They were elected to these portfolios through criteria such as their participation as community builders, their perceived commitment, passion for education and their leadership qualities.

\section{(b) The Methods Used by the SGBs to Execute their Duties and the Rationale for the Choice}

In the absence of face-to-face engagements, the three principals reported on utilising cell phone calls to communicate with the SGBs. Similarly, one of the SGB chairpersons (School B) also reported using cell phone voice calls to communicate with some of his peers.

With regards to using cell phone voice calls, as a preferred method of communication, Principal A (a principal from School A) reported:

As most of the SGBs are elderly and not very educated, we are forced to make use of what is familiar to them, which is cell phone voice calls. They are more familiar, convenient and faster [than other means].

The SGB chairperson from School A supported the principal and explained, 'during lockdown, we could not meet face-to-face. The principal could only use the cell phone to call us'. He further noted that as parent-SGB members, they were not familiar with other means of communication that included emails and WhatsApp messaging.

Similarly, Principal C said:

I phone the SGB when I want to communicate something to them. SGB members are more comfortable with SMS and cell phone voice calls.

Even though School B reportedly used WhatsApp messaging for engagement, there was a minority of SGB members whose cell phones were reportedly not compatible with WhatsApp messaging, as the SGB chairperson reported:

Sometimes other SGB members are not as equipped as I do [am]. 
They still make use of tilili phones [phones that are not smart phones]. I have to call such members so that they are not left behind [regarding developments]. I know I am right about requesting government to provide us with proper cellular phone gadgets.

Commenting on 'tilili' phones, Principal B explained that these are the phones that are not WhatsApp compatible. As a result, the SGB chairperson $\mathrm{B}$ had to call them using his airtime. The 'tilili' phones were also reported at School C, where most SGB members could only be communicated with through voice calls and SMS.

Regarding the use of WhatsApp messaging at School B, the principal, reported the following, which seemed to corroborate what the SGB Chairperson B had already reported on:

The chairperson then conveys the message to other SGB members ... those who do [did] not have the WhatsApp facility, he called them.

Even though School B made use of cell phone voice calls, as explained above, they also reportedly utilised WhatsApp messaging. In fact, they used and preferred WhatsApp messaging. The principal intimated:

During the COVID lockdown, especially [alert] Level 5 and 4 [with the greatest restriction], we used specifically WhatsApp messaging. It was not difficult, as we had [the] particulars of all SGB members, which we collected the day they got elected. Therefore, we communicated mainly using WhatsApp messaging.

This was corroborated by the SGB chairperson who claimed:

When the Department of Education suspended classes due to COVID-19, I used my cell phone to interact with the principal. With my Standard 6 [Grade 8] education, I am able to type WhatsApp messages to the principal. Thereafter, I can circulate [messages] to the rest of the SGB committee through the WhatsApp group that was created by the principal.

The principal and SGB chairperson from School B both reported that they 
preferred WhatsApp messaging because it was 'the only available, easiest and cost-effective channel'. Furthermore, they 'were more familiar and comfortable with it, even before lockdown'.

Amongst the three participating schools, it was only in School B where there was evidence of communication between the principal and the SGB chairperson, through WhatsApp messaging. For instance, SGB chairperson $\mathrm{B}$, amongst others, had documents forwarded to him by the principal, which were from the Department of Basic Education (DBE) as well the Teacher Union(s).

From the above information, it can be noted that the schools made use of the cell phones as the main method of communication. Furthermore, cell phones were reported as the most preferred, convenient and cost-effective channel. Amongst the three schools that participated in the research, only one school could produce evidence of engagement through SMS messaging. Others only provided verbal reports that this had taken place. Some SGBs apparently knew about email use but could only link this to teacher use.

Of the three participating schools, only one seemed to use the WhatsApp facility. Using WhatsApp messaging was also dependent on the type of the cell phone one possessed. Even in School B, where WhatsApp messaging was the main mode of communication, there were SGB members whose cell phones could not be used for WhatsApp messaging purposes. This school is based in the township context, whereas the other two are in rural areas. This may imply that the use of cell phones for SGB communication may have not be influenced by age but on the context in which SGB participants find themselves. SGB chairpersons from schools A and B were of the same age (age 66), with the former more educated than the latter.

\section{(c) Decisions taken through the Medium of Cellular Phones}

Even though SGBs were restricted in gathering, governance and management of schools had to continue in the midst of the COVID-19 pandemic. The SGBs used different platforms to make decisions. This means that schools had to adopt means to continue operating, thus SGBs were forced to use alternative modes of communicating and make key strategic decisions regarding their respective schools. On one hand, two schools (Schools A and C) communicated and agreed on governance using cell phone voice calls. School B relied on WhatsApp messaging for communication, 
and one school (School C) made use of the Chief's Great Place for meetings, which are always face to face even in the face of a pandemic.

When asked about decisions the SGB took during the COVID-19 lockdown, Principal C reported:

During the COVID-19 lockdown period, communication was through the Chief. The Chief is the one who has access to the community. He communicates through the loudspeaker with [in] different villages [delivering] all messages with [to] the parents. The meeting had to decide on the adoption of the school budget.

Another decision that was reportedly taken, was the report back from the DBE and Teacher Unions on school closure, School B used another platform, which was WhatsApp messaging. Principal B commented:

For instance, due to the COVID-19 Disaster Management Proclamation, schools were supposed to close on the 20th of March, but all of a sudden, were told to close on the 18th March, two days before the actual school calendar policy. We, therefore, had to inform the SGB of the instruction from the Department through WhatsApp [messaging].

School B also used WhatsApp messaging to discuss the levels of school readiness for the reopening was confirmed by the SGB chairperson who declared:

When schools were about to re-open, I sent the principal a message on WhatsApp suggesting that we needed to check school readiness.

School A used cell phone voice calls to make plans to ensure school safety during COVID-19 alert levels 4 and 5. In Schools A and B, respectively, there were debates around the security of the school infrastructure during lockdown. For instance, when Principal A was probed about the security of the infrastructure, he said:

We could not convene meetings during the lockdown; however, there were some decisions made regarding school security that were 
taken despite the lockdown due to fear that school could be vandalised.

On the other hand, SGB Chairperson B reported on the discussion between himself and the principal in which the former was concerned about the risk level of learners when they returned after the COVID-19 lockdown. He reported:

I also wanted to check if the school would be able to screen everyone coming into the school so that we know who is likely to be infected so that the school [could] become a COVID-19 safe space.

Another decision taken during the lockdown was about procurement, where the principal would request via cell phone calls for SGB members to converge at the Chief's Great Place. Principal C reported:

During lockdown we phoned the SGB chairperson, the secretary and the treasurer to confirm transactions that needed to be processed as it was not possible to hold Procurement Meetings, as we would do before lockdown. They agreed reluctantly to sign, as I would meet them at the Chief's Place to sign the cheque.

As much as SGB operations are ideally managed through robust discussions and debates, there was little evidence of such engagement in the schools under study. For instance, it can be noted from the above excerpt that in School $\mathrm{C}$ there were no face-to-face discussions among the SGB members and where SGB members had to interact, this was limited to the signing of cheques in a venue other than the school, the Chief's Place. This could be attributed to the fact that the ICT tool, which is a cell phone in this case, was the main medium of communication.

However, its use was limited to calling SGB members to request them to converge in a Chief's Great Place. Although the cell phone appeared to be the main medium of communication during the COVID-19 lockdown, there were some connectivity challenges. For instance, Schools A and C were reported to be negatively affected by poor network connectivity, whilst in School B, where such limitations were not experienced, there was little evidence of robust discussions on school governance matters. For instance, 
SGB Chairperson B reported receiving documents which reported and sometimes instructed on the closure or reopening of schools and the adherence to COVID-19 protocols.

Even documentary evidence from SGB Chairperson B was a collection of PDF files from the DBE and from major Teacher Unions. Importantly, this was the only school that produced evidence of such documents. This may be indicative of decisions about schools being made without the presence of the entire SGB members present in a formal meeting as required by the legislation.

\section{(d) Enhancing School Governance during the COVID-19 Era}

Even though participants reported on the progress made by the schools during lockdown, there were also some challenges and limitations identified. These include the community infrastructure, human capital and the physical infrastructure.

With regard to the community infrastructure, participants from Schools A and C were concerned about the lack of network connectivity and sometimes could not communicate using their cell phones. Both schools are located in rural villages.

As much as the schools preferred cell phone utilisation and WhatsApp messaging in particular, a limitation was raised about the poor quality/ limited application cell phones which some SGB members possessed (Tilili phones). Therefore, both the principal and SGB chairperson (from School B) were of the view that the government needs to provide SGBs with 'tools of work'. These, according to them include laptop computers, an appropriate smart phone, data and airtime. This implies that, participants suggested a policy to cater for the use of ICT towards the SGB's basic functionality. The principal was hopeful that if the SGB-parents were trained in the use of ICT tools, they would learn to use them as they were already utilising them for their pension pay-outs. There was also a suggestion that more youthful parents be elected onto SGB committees. This is based on the view of having a generational mix in school governance as younger members of the SGBs would share skills on how to utilise the proposed ICT gadgets in executing their duties during the COVID-19 era.

The findings above of the study are linked to the theoretical framework and relevant literature discussed earlier and lead to the formation 
of themes. The major themes were: Masculinity and Old age; SGBs embracing cell phones as the main medium of communication; ICT platforms such as cell phones used as pseudo-participation of SGB/ proactive policy formulation; little evidence of realistic discussion on school governance. With regards to profiles of SGB chairpersons, the study found that old age, being male and lower levels of education characterised leadership. Furthermore, all the chairpersons (from rural schools) were unemployed, and therefore 'available'. Duku (2006) links the inclusion of only or mostly males in SGBs to an African traditional belief system that associates authority and leadership with men. These profiles are in line with studies, amongst others, of Duku (2006), Mncube (2009) and Kombela (2019). According to these researchers, these profiles are likely to affect their relationship with the principal and teachers in terms of power relations.

In line with Van Manen's (1990; 2017) and Haussler's (1987) Theory of Lived Experiences, all SGBs in the study seemed to have expressed a keen interest in embracing and learning more about the utilisation of ICT Tools (smart phones) in school governance. For instance, SGB chairperson A noted that even though he is not familiar with emails and WhatsApp messaging, he was keen to learn. Even where there is discomfort and reluctance in using cell phones, there seemed to be an understanding that cell phones and other ICT tools are a relevant alternative and the future vehicle for effecttive governance of schools. For instance, Principal B and SGB Chairperson B suggested that SGB members should be provided with ICT devices, and that training on the use of ICT platforms should be mandatory. As Tosun and Baris (2011) claim, ICT has become an indispensable part of our everyday life. This is despite technology-related challenges experienced by SGB members that include network coverage and limited resources to purchase appropriate cell phones, airtime and data. The use of ICT, according to Tosun and Bariş (2011), brings cost challenges as well as cultural and structural inequalities to the fore. Hence, moving forward, the study recommends ICT use to be included in policies and in the training of SGB members.

With regards to making decisions using cell phones, it emerged from the data that all two schools use these platforms to make to communicate decisions; however, data showed that SGB members were pseudoparticipants as principals seemed to dominate decision-making processes using cell phones during lockdown. This is what Mavuso and Duku (2014) referred to as pseudo-participation in school governance. 


\section{Conclusion}

This paper explored the experiences of representative of a sample of SGBs in executing their duties during the COVID-19 lockdown in spite of the lack in appropriate ICT tools and connectivity challenges. The findings explicitly indicated that using ICT tools such as cell phones in governance were inevitable and desirable in modern times. The study, over and above, inferred that the cell phone as a medium of communication for school governance is not exclusively confined to a particular context, even though there are limitations in each context, like network connectivity. Evident in this study was the dominance of patriarchy expressed through male leadership in the governance of schools under study, which has been widely reported by other scholars as well. For SGBs to be compliant and relevant in the COVID-19 context, this study, suggests mandatory utilisation of ICT tools in school governance, not only to make schools 4IR relevant and compliant, but also to empower and improve school governors in their basic functionality. Also, a concern has been raised by previous studies on the pensionable-age of members of parent-SGBs. This study recommends a generational mix in the election of SGBs, thus encouraging the involvement of working-age adults in school governance as opposed to only retirees.

\section{References}

Almalki, S. 2016. Integrating Quantitative and Qualitative Data in Mixed Methods Research: Challenges and Benefits. Journal of Education and Learning 5,3: 288-296. https://doi.org/10.5539/jel.v5n3p288

Balarin, M. Brammer, S. James, C. \& McCormack, M 2008. The School Governance Study: Governing our Schools. A Research Study Commissioned by Business in the Community, October 2008.

Bayat, A., W. Low \& R. Rena 2014. The Role of School Governing Bodies in Underperforming Schools of Western Cape: A Field Based Study. https://www.researchgate.net/publication/286486481 https://doi.org/10.5901/mjss.2014.v5n27p353

Babbie, E. \& J. Mouton 2006. The Practice of Social Research. Cape Town: Oxford University Press.

Bush, T. \& J. Heystek 2003. School Governance in the New South Africa: A Journal of Comparative and International Education 33,2: 127 - 138. 
Ntombozuko Duku, Percival Mzuyanda Mavuso \& Moses Sipho Mkhomi

\section{https://doi.org/10.1080/0305792032000070084}

Burgess, S. \& H.H. Sievetsen 2020. School, Skills and Learning: The Impact of COVID-19 on Education and Learning.

https://voxeu.org/article/impact-covid-19-education (Accessed on 16 September 2020.)

Caldwel, B. \& J.M. Spinks 1998. Beyond the Self-Managing School.

Routledge. https://www.routledge.com/Beyond-the-Self-Managing-

School/Caldwell-Spinks/p/book/9780750704489

City Press 2020. STEM Digital School Launched Teachers Required for e-

Learning during Lockdown.

https://www.news24.com/citypress/news/stem-digital-school-

launched-teachers-required-for-e-learning-during-lockdown-20200402

(Accessed on 20 October 2020.)

Chikoko, V. 2008. The Role of Parent Governors in School Governance in Zimbabwe. Perception of School Heads, Teachers and Parents. International Review of Education 54: 243-263.

https://doi.org/10.1007/s11159-007-9080-x

Constitution of Republic of South Africa 1996. Pretoria: Government Printers.

Creswell, J.W. 2014. Research Design: Quantitative, Qualitative and Mixed Method Approaches. London: SAGE.

De Vos, A.S., S. Schulze \& L. Patel 2005. The Sciences and the Professions. In De Vos, A.S., H. Strydom, C.B. Fouché \& C.S.L. Delport (eds.): Research at the Grassroots for the Social Sciences and Human Service Professions. $3^{\text {rd }}$ Edition. Pretoria: Van Schaik.

Duku, N. 2006. The Exploration of African Parents' Negotiation of their Identities in School Governance Participation in Six Selected Eastern Cape Communities. Unpublished $\mathrm{PhD}$ Thesis, University of Cape Town.

Duku, N. \& B. Brown 2008. Negotiated Identities: Dynamics in Parents'

Participation in School Governance in Rural Eastern Cape Schools and Implications for School Leadership. South African Journal of Education 28,3. https://doi.org/10.15700/saje.v28n3a122

Duku, N. \& I.A. Salami 2017. The Relevance of SGBs to the Effective Decolonisation of Education in South Africa. Perspectives in Education 35,12: $112-125$.

https://doi.org/10.18820/2519593X/pie.v35i2.9 
Edward, E.J. 2005. Type-A Behaviour, Gender, and Job Satisfaction in Schools: Research on Instructors. Educational Sciences: Theory and Practice 13,3: 1455 - 1459.

Eun, B. 2008. Making Connections: Grounding Professional Development in the Developmental Theories of Vygotsky. The Teacher Educator 43: 134 - 155. https://doi.org/10.1080/08878730701838934

EWN 2020. Lockdown Lessons: SA Pupils Turn to Online Learning to Keep Studies on Track. http://ewn.co.za/2020/04/01/lockdown-lessons-sapupils-turn-to-online-learning-to-keep-studies-on-track

(Accessed on 25 September 2020.)

Farrell, C.M. \& J. Law 1999. The Accountability of School Governing Bodies. Educational Management \& Administration 27: 5 - 15.

https://doi.org/10.1177/0263211X990271001

Fraenkel, J.R. \& N.E. Wallen 2006. How to Design and Evaluate Research in Education. New York: McGraw-Hill.

Gann, G. 1998. Improving School Governance. How Better Governors Make Better Schools. London: Falmer Press.

Heystek, J. 2003. Parents as Governors and Partners in Schools. Sage Journal 25,3: 328 - 351.

https://doi.org/10.1177/0013124503035003005

Heystek, J. 2011. School Governing Bodies in South African Schools: Under Pressure to Enhance Democratization and Improve Quality. Educational Management Administration \& Leadership 39: 455.

https://doi.org/10.1177/1741143211406149

Huber, S.G. 2011. School Governance in Switzerland: Tensions between New Roles and Old Traditions. Educational Management, Administration \& Leadership 39,4: 669 - 485.

https://doi.org/10.1177/1741143211405349

Ibrahim, A. 2012. Thematic Analysis: A Critical Review of its Process ad Evaluation. Croatia: Zagreb.

IOL 2020. SA Learners Gain Access to Unlimited and Free Online Education during Lockdown.

https://www.iol.co.za/technology/software-and-internet/sa-learnersgain-access-to-unlimited-and-free-online-education-during-lockdown45891281 (Accessed on 18 September 2020.)

Johnson, K.E. 2009. Second Language Teacher Education: A Socio-cultural Perspective. New York, London: Routledge. 
Kombela, T.W. 2019. The Influence of Educational Levels of the Parent School Governing Body Component on their Participation in School Governance in Rural Primary Schools of the East London Education District. Unpublished MEd Dissertation, University of Fort Hare.

Lai, E.R. 2011. Collaboration: A Literature Review - Research Report. http://www.pearsonassessments.com/research (Accessed in June 2011.) Levy, B. \& L. Shuman 2017. School Governance in Fragmented Political and Bureaucratic Environment: Case Studies from South Africa: Eastern Cape Province. Occasional Paper No 7, Graduate School of Development Policy and Practice, UCT.

https://doi.org/10.2139/ssrn.2956313

Li, W., C. Bruce \& H. Hilary Hughes 2011. Sociocultural Theories and their Application in Information Literacy Research and Education. Australian Academic \& Research Libraries 42,4: 296 - 308.

https://doi.org/10.1080/00048623.2011.10722242

Mashego, D.D. 2000. Collaboration as an Aspect of Leadership: Implications to School Effectiveness. MEd dissertation. Johannesburg, South Africa: Rand Afrikaans University. Available at:

https://core.ac.uk/download/pdf/18219642.pdf (Accessed on 17 March 2019.)

Maree, K. 2007. First Steps in Research. Pretoria: Van Schaik.

Mavuso, M.P. 2009. An Exploration of the Roles of SGB Members: A Case Study of Two Selected Rural Primary Schools in the King Williams Town Education District. Unpublished MEd Dissertation, University of Fort Hare, South Africa.

Mavuso, M.P. \& N. Duku 2014. Participation of Parents in School Governance: A Case Study of Two Eastern Cape Schools: A View from Below. Mediterranean Journal Social Sciences 5,3.

https://doi.org/10.5901/mjss.2014.v5n3p454

McCrone T., C. Southcott \& N. George 2011. Governance Models in Schools. Pretoria: National Foundation for Educational Research.

Mestry, J. 2006. The Functions of School Governing Bodies in Managing School Finances. South African Journal of Education (EASA) 26,1: 27 -38 .

Mncube, V. 2007. Social Justice, Policy and Parents' Understanding of their Voice in School Governing Bodies in South Africa. Journal of Educational Administration and History 39,2: 129 - 143. 
https://doi.org/10.1080/00220620701342395

Mncube V. 2009. The Perceptions of Parents of their Role in the Democratic Governance of Schools in South Africa: Are they on Board? South African Journal of Education 29: 83 - 103.

https://doi.org/10.15700/saje.v29n1a231

Munje, P.N. \& T. Jita 2020. The Impact of the Lack of ICT Resources on Teaching and Learning in Selected SA Primary Schools. International Journal of Learning, Teaching and Education Research 19,7: 263 - 279. https://doi.org/10.26803/ijlter.19.7.15

Okeke, C. \& M. van Wyk (eds.). 2015. Educational Research: An African Approach. Cape Town: Oxford: University Press.

Olssen, M. \& M.A. Peters 2005. Neoliberalism, Higher Education and the Knowledge Economy: From the Free Market to Knowledge Capitalism. Journal of Education Policy 20,3: 313 - 345.

https://doi.org/10.1080/02680930500108718

Padayachee, K. 2017. A Snapshot Survey of ICT Integration in SA Schools. South African Computer Journal 29,2.

https://doi.org/10.18489/sacj.v29i2.463

Peacock, P. September 2006. Scottish Schools. (Parental Involvement) Act 2006. Scottish Executive.

Ratheeswari, K. 2018. Information Communication Technology in Education. Department of Value Education, Tamilnadu Teachers Education University, Chennai, Tamil Nadu, India.

Sayed, Y. \& M. Singh 2020. Evidence and Education Policy Making in South Africa during COVID-19: Promises, Researchers and Policymakers in an Age of Unpredictability. Southern African Review of Education 26,1: $20-39$.

Sotuku, N. \& S. Duku 2015. Ethics in Human Sciences Research. In Van Wyk, O.A. 9ed.): Educational Research: An African Approach. Cape Town: Oxford University Press Southern Africa (Pty) Ltd.

South African School Act of 1996. Department of Education, Republic of South Africa.

Soudien, C. 2020. Systemic Shock: How COVID-19 Exposes our Learning Challenges in Education. Southern African Review of Education 26,1: 6 -19 .

Tashakkori, A. \& C. Teddlie 2010. Sage Handbook of Mixed Methods in Social \& Behavioural Research. $2^{\text {nd }}$ Edition. London: Sage. 
Ntombozuko Duku, Percival Mzuyanda Mavuso \& Moses Sipho Mkhomi

https://doi.org/10.4135/9781506335193

Tosun, N. \& M.F. Bariş 2011. Using Information and Communication Technologies in School Improvement. The Turkish Online Journal of Educational Technology 10,1.

Xaba, M.I. 2011. The Possible Cause of School Governance Challenges in South Africa. South African Journal of Education 31: 201 - 211. https://doi.org/10.15700/saje.v31n2a479

Walqui, A. 2006. Scaffolding Instruction for English Language Learners: A Conceptual Framework. International Journal of Bilingual Education and Bilingualism 9: 159 - 180.

https://doi.org/10.1080/13670050608668639

United Nations Children's Fund (UNICEF) March 2020. Key Messages and Actions for COVID-19: Prevention and Control in Schools.

Van Manen, M. 1990. Researching Lived Experiences: Human Science for an Action Sensitive Pedagogy. Albany: State University of New York Press.

Van Manen, M 2017. But What is Phenomenology? Qualitative Health Research 27: 775 - 779. https://doi.org/10.1177/1049732317699570 PMid:28682717

Professor Duku Ntombozuko University of Fort Hare nduku@ufh.ac.za

Professor M.P. Mavuso University of Fort Hare pmavuso@ufh.ac.za

Dr. M.S. Mkhomi University of Fort Hare smkhomi@ufh.ac.za 